\title{
Biology and Control of Cogongrass (Imperata cylindrica) in Southern Forests ${ }^{1}$
}

\author{
Patrick J. Minogue, Brent V. Brodbeck, and James H. Miller ${ }^{2}$
}

\section{Cogongrass Biology}

Cogongrass (Imperata cylindrica (L.) Beauv.) is a warmseason perennial grass species found throughout tropical and sub-tropical regions of the world (Hubbard 1944). Native to Southeast Asia, cogongrass is an aggressive invasive plant that that has spread to all continents except Antarctica (MacDonald 2004) and is considered among the worst problematic weeds on a global scale (Holm et al. 1977). In the United States, it is naturalized in Virginia, North Carolina, South Carolina, Georgia, Florida, Alabama, Mississippi, Louisiana, Texas, and Oregon (USDA Plants 2017). It was first accidentally introduced in the United States near Mobile Alabama in 1912 (Tabor 1949 and 1952, Dickens 1974) and subsequently intentionally introduced from the Philippines into Mississippi as a forage crop in 1921 (Tabor 1949 and 1952, Patterson et al. 1979, Tanner and Werner 1986). Plants from Mississippi were replanted in Florida for forage and soil stabilization in the 1930s (Tabor 1949, Hall 1983, USDA NISIC 2017), though its high silica and low protein content made cogongrass an inadequate forage crop (Coile and Shilling 1993, Garrity et al. 1993). These early regional introductions contributed to the establishment of cogongrass in the Southeast. Points of introduction, including forage trials, are often areas where cogongrass remains most well established (Willard et al. 1990). Cogongrass is regulated as a federal noxious weed (USDA Plants 2017).
Control of cogongrass is difficult because it spreads in two ways: by extensive rhizome systems and by seeds (Holm et al. 1977, Brook 1989). Cogongrass rhizomes can comprise more than $60 \%$ of the total plant biomass. The rhizomes support rapid re-growth following mowing or burning (Sajise 1976). The fibrous root system grows from nodes on branched rhizomes that form a dense mat able to exclude most other vegetation (Ayeni 1985), and may contribute to rapid re-growth following cutting, disking, or burning (Sajise 1976, Ramsey et al. 2003). Rhizomes are tough and white and are covered with light brown colored cataphylls (scale leaves), which form a protective sheath. They have short internodes and sharp root caps (Ayeni 1985). The aboveground plant has no stems, although individual leaves may reach nearly 5 feet in length (Holm et al. 1977, Bryson and Carter 1993). Leaves exhibit a distinct lime green color and are slender, flat, and linear-lanceolate with serrated leaf margins and a prominent, typically off-center white mid-rib (Hubbard 1944, Holm et al. 1977).

The importance of seeds in the spread of cogongrass in the southeastern United States is less clearly established than the importance of roots (Dozier et al. 1998, Willard et al. 1990, MacDonald 2007, Ludovic et al. 2008). Cogongrass produces prolific seeds (c 3,000 per plant) from compacted, cylindrical, shortly branched, spike-like, fluffy, white plumes 4 to 8 inches long. Seeds can travel long distances

1. This document is FR342, one of a series of the School of Forest Resources and Conservation, UF/IFAS Extension. Original publication date March 2018. Visit the EDIS website at http://edis.ifas.ufl.edu.

2. Patrick J. Minogue, associate professor; Brent Brodbeck, senior biological scientist, School of Forest Resources and Conservation, UF/IFAS North Florida Research and Education Center; and James H. Miller, emeritus scientist, USDA Forest Service, George Andrews Laboratory; UF/IFAS Extension, Gainesville, FL 32611.

The Institute of Food and Agricultural Sciences (IFAS) is an Equal Opportunity Institution authorized to provide research, educational information and other services only to individuals and institutions that function with non-discrimination with respect to race, creed, color, religion, age, disability, sex, sexual orientation, marital status, national origin, political opinions or affiliations. For more information on obtaining other UF/IFAS Extension publications, contact your county's UF/IFAS Extension office. 
(Hubbard 1944, McDonald et al. 1996), but generally seed movement averages $16 \mathrm{ft}$ (Holm et al. 1977, McDonald et al. 1996). Although seeds are potentially highly germinable (more than $90 \%$ of the seeds will sprout), low spikelet fill often results in much lower germination rates (Schilling et al. 1997, Dozier et al. 1998, Burnell et al. 2003). There may be regional differences in seed viability. Viable seeds have been reported in Florida, Mississippi, and Alabama, but large areas of cogongrass infestation in central Florida do not produce fertile seed (MacDonald 2007). Cogongrass is an obligate outcrossing species; therefore, populations arising from rhizomes persist vegetatively until they grow in close proximity to genetically different populations and produce viable seed (McDonald et al. 1996, Dozier et al. 1998, MacDonald 2007). Seeds have no dormancy, and seed viability declines rapidly, with a complete loss in viability after one year (Schilling et al. 1997, Dozier et al. 1998). Patterns of molecular analyses of stands of cogongrass in different locals suggests that successful long-range dispersal may be due to human activity rather than typical wind dispersal of seeds (Ludovic et al. 2008).

\section{Control of Cogongrass}

Although cogongrass has many natural pests, including more than 80 pathogens, 90 insects, and several nematodes and mites reported worldwide (Van Loan et al. 2002), in biological control studies insects and fungi have been shown to be generally ineffective (Ivens 1980, Brook 1989, MacDonald 2007). Recently, surveys in Asia an East Africa for potential biological control agents, identified several insect herbivores, including several genera of stem borers and gall-forming midges, that show some promise. Based on life histories and field collection data, it appears these genera may have restricted host ranges (Overholt et al. 2016).

Establishment of competing vegetation has been more successful in controlling the spread of cogongrass. Bahiagrass (Paspalum notatum Fluegge) sod cover has been effective in managing cogongrass infestations in the southeastern United States (Shilling et al. 1997, Willard and Shilling 1990). Common hulled bermudagrass (Cynodou doctylon (L.) Pers.) and hairy indigo (Idigofera hirsuta Harvey) have also inhibited cogongrass establishment (Gaffney 1996), but bahiagrass, bermudagrass, and hairy indigo are non-native and are also potentially invasive in forests and natural areas. In Indonesia, establishment of forests with understory cover crops has been effective in suppressing, but not eradicating, cogongrass (Macdicken et al. 1997). Deep shade has been shown to reduce cogongrass establishment (Otsama et al.
1995, Ramsey et al. 2003); fast-growing legumes such as velvetbean have been used successfully in other countries (Chikoye et al. 2002).

Mechanical control alone has been shown to be ineffective once cogongrass is established. Burning of cogongrass produces unusually hot fires because of the fuel characteristics of the aboveground biomass. The sandhills of the southeastern United States support a pyrogenic pine savanna ecosystem sustained by relatively frequent lowintensity fires fueled by native grasses and pine needle-fall. Lippincott (2000) found that cogongrass invasions into this ecosystem significantly increase fine fuel loads, resulting in fires that are more horizontally contiguous and have greater fire heights and higher maximum temperatures. These cogongrass-fueled fires kill juvenile longleaf pine (Pinus palustris Mill.). The cogongrass rhizome system is able to persist following fire, whereas many other types of vegetation do not (Eussen and Wirjahardja 1973; Seavoy 1975). Cogongrass patches have been shown to be more numerous and larger in recently burned plots (Holzmueller and Jose 2012). Mowing can temporarily inhibit and remove cogongrass biomass above the ground, but mowing does not suppress cogongrass long-term (Willard et al. 1996). Repeated disking and deep plowing have been shown to be effective in suppressing or eradicating cogongrass in intensive agricultural settings, but these practices are impractical in many habitats such as forests or natural plant communities (MacDonald 2004).

In forests, the only effective method for suppression or elimination of existing patches of cogongrass is chemical control. A body of research in the southeastern United States has identified glyphosate, imazapyr, and combinations of these herbicides as effective in managing cogongrass, although complete control is achieved only with repeated applications (Willard et al. 1996 and 1997, Shilling et al. 1997, Dozier et al. 1998, Johnson 1999, Ramsey et al. 2003). Both glyphosate and imazapyr are readily absorbed and translocated to rhizomes (Townson and Butler 1990). Used alone, imazapyr is more effective than glyphosate (Willard et al. 1996, Dozier et al. 1998, Ramsey et al. 2003), but imazapyr is a broad-spectrum, persistent, soil-active herbicide that often causes damage to non-target vegetation, particularly hardwood trees and shrubs. Cogongrass control is most effective at the higher labeled rates of glyphosate or imazapyr, and the most effective time of application is in late summer or fall (Shilling et al. 1997, Willard et al. 1997, Ramsey et al. 2003). Combinations of glyphosate and imazapyr in various proportions were equally effective as the highest rate tested for these 
herbicides used alone (Willard et al. 1997). Additions of surfactants and the adjuvant methylated seed oil (MSO) also increase efficacy of chemical control (Ramsey et al. 2012). Mechanical techniques (such as tillage) or burning about six weeks before herbicide application may also enhance suppression by glyphosate and imazapyr (Willard et al. 1996, Ramsey et al. 2003, Enloe et al. 2013). Aulakh et al. (2014) reported progress toward complete eradication of patches of cogongrass using mixtures of glyphosate and imazapyr, but only after multiple applications over a 3-year period. However, most studies result in suppression rather than eradication, suggesting the need for examination of multiple applications and/or higher rates of glyphosate and imazapyr.

\section{Recommendations}

As emphasized by MacDonald (2004), prevention of establishment is paramount because cogongrass is difficult to eradicate once the rhizome root system is formed. Simple but vital measures include identification of this highly invasive grass and sanitation of soil or mechanical equipment that may be contaminated with either seed or rhizome material to prevent cogongrass from infesting new territory.

Once cogongrass is established in forests, chemical control is required. Glyphosate, imazapyr, and combinations of the two herbicides are most effective, but eradication requires multiple applications. In many instances, selective control of cogongrass without damage to desired vegetation is not possible, but where the canopy of shrubs and trees is above that of cogongrass, glyphosate sprays may be directed to cogongrass in the understory with fair selectivity to the taller vegetation.Imazapyr, however, used in the quantities and at the application frequencies necessary to eradicate cogongrass, will kill hardwood trees and shrubs.

\section{Cogongrass Management in Mixed Pine- Hardwood Forests}

To avoid injury to hardwood trees or shrubs in mixed pinehardwood stands, glyphosate alone is commonly used at 3 to $4 \mathrm{lb}$ ai/acre ( 3 to 4 quarts per acre for many common $4 \mathrm{lb}$ ai/gallon product formulations), and selectivity is obtained by spraying cogongrass in the understory and avoiding any spray contact near the crowns of trees and shrubs. Typically, cogongrass excludes other ground cover plants, but herbaceous plants growing at the same height as cogongrass will be sacrificed when sprayed. Cogongrass infestations start as a small patch, and this is the best time to begin eradication. For patches, a "spot treatment" using $4 \%$ percent glyphosate product (a product formulation containing $4 \mathrm{lb}$ ai glyphosate per gallon) in water is commonly used. Rates of ai applied per acre will increase as spray volumes used increase. Selectivity is obtained by not spraying the foliage of desirable plants. Glyphosate is strongly absorbed by the soil, so uptake through root systems is not a concern.

Glyphosate products contain varying amounts of surfactants, which improve herbicide uptake by the foliage of treated plants. The addition of $1 \%$ methylated seed oil (MSO) to the spray solution is recommended to slow drying time on the leaf surface and further improve herbicide uptake by cogongrass foliage (Ramsey et al. 2012). The best time to apply glyphosate depends on location. It is best to make applications before cogongrass begins to go into dormancy. For infestations along the Gulf Coast, late summer (September) is the best time, but later applications may be more effective in the Florida peninsula.

Retreat after a year, or after two years, to control regrowth in persistent patches. Established cogongrass stands may require additional applications but can be eradicated with persistence (Aulakh et al. 2014). Following cogongrass eradication, revegetation with other competitive grasses or groundcover and fast-growing, shade-producing shrubs and trees may reduce the likelihood of cogongrass becoming re-established.

\section{Cogongrass Management in Pine Forests}

Because southern pines are tolerant to imazapyr, this herbicide may be used alone or in combination with glyphosate to control cogongrass selectively in pine forests. We conducted field research in pine plantations to examine herbicide rate response over a wide range for both glyphosate and imazapyr (Minogue et al. 2012). We tested 1.5 to $12 \mathrm{lb}$ ai/acre glyphosate and 0.25 to $2.0 \mathrm{lb}$ ae/acre imazapyr, using higher rates than had been used in previous research. We also examined the efficacy of a common combination of $3.0 \mathrm{lb}$ ai/acre glyphosate and $0.5 \mathrm{lb}$ ae/acre imazapyr with varying application volumes from 10 to $40 \mathrm{gal} / \mathrm{acre}$. All treatments included $0.5 \%$ non-ionic surfactant. To refine previous research, we examined two late growing season application timings, when herbicide treatments have been shown to be most effective (mid-September versus midOctober). Lastly, effects of retreatment one year after the initial treatment were quantified. The study was duplicated in southwest Alabama at a location where cogongrass had been present for over twenty years in a planted slash pine forest and at a new infestation in a two-year-old loblolly pine plantation. Both sites had similar, near-complete 
cogongrass cover (96-100\%) at the initiation of the experiments. The sites were chosen because they were within 40 miles of the site where cogongrass was first introduced in the United States, and this area still contains some of the most abundant infestations of cogongrass in the Southeast.

Our research in these pine stands showed that, for both glyphosate and imazapyr, control of cogongrass increased linearly with increasing herbicide rate (Figure 1). In general, a single application of the highest rate of each herbicide, far above labeled rates, resulted in only 53 to $89 \%$ control, and, with retreatment, control ranged from 77 to $89 \%$ after two years, indicating the need for additional treatment to attain eradication. Retreatment improved control with glyphosate at both the new and old infestations. Retreatment with imazapyr improved control at the new infestation, but at the old infestation, differences in control following retreatment diminished with increasing imazapyr rate. Whereas cogongrass control improved with increasing herbicide rate, increasing application volume from 10 to 40 gallons per acre for the glyphosate plus imazapyr combination treatment did not improve control. When averaged over all treatments, efficacy was greater when treatments were applied in September compared to October.
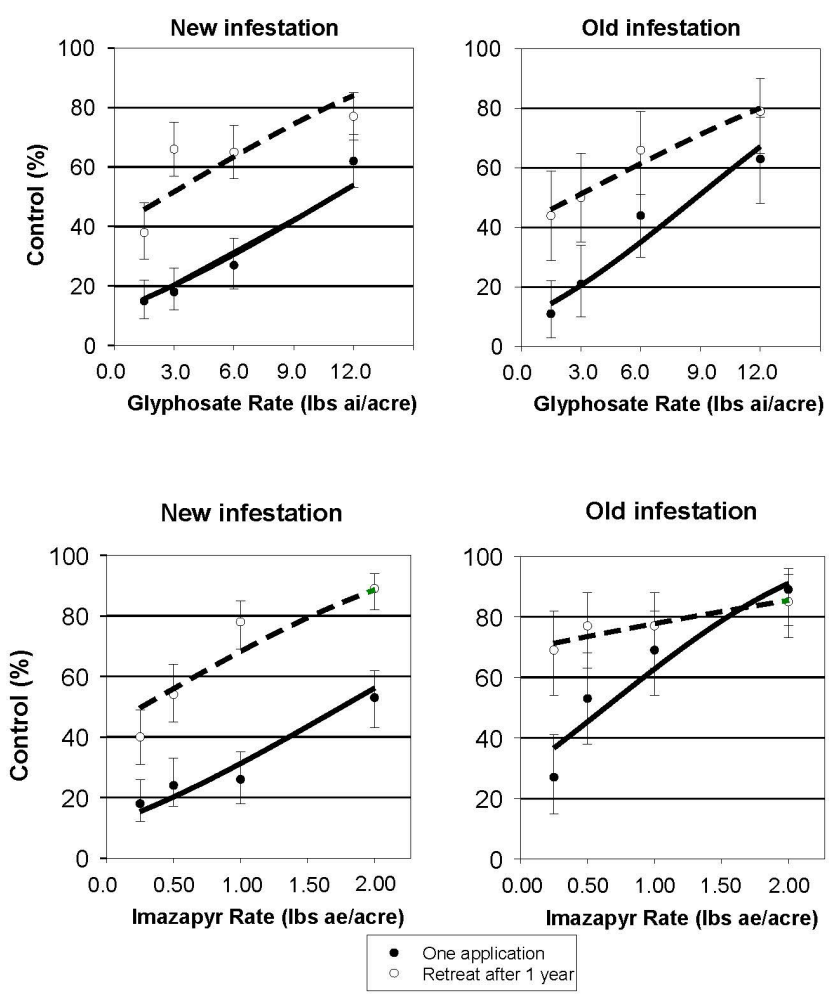

Figure 1. Percent control of cogongrass 2 years after treatment and 2 years after retreatment for various rates of glyphosate and imazapyr in old and new cogongrass infestations. Error bars are \pm 1 standard error. Credits: Abstracted from Minogue et al. (2012). South. J. Appl. For. 36:19-25
Imazapyr may be applied to selectively control cogongrass in the understory of pine stands using selective "Pine Release Treatments" described on the product labels. Rates up to $0.625 \mathrm{lb}$ ae/acre imazapyr ( $20 \mathrm{oz}$ Arsenal AC or 40 oz Chopper product) may be used in loblolly pine stands, and rates up to $0.5 \mathrm{lb}$ ae/acre imazapyr ( $16 \mathrm{oz}$ Arsenal or $32 \mathrm{oz}$ Chopper product per acre) may be used in slash or longleaf pine (see product labels for other pine species). However, on sandy soils, pine damage may occur at these rates because of greater herbicide uptake from the soil by pine roots. On sandy sites, $0.5 \mathrm{lb}$ ae/acre imazapyr should be the upper limit for loblolly pine, and rates should not exceed $0.4 \mathrm{lb}$ ae/acre in slash or longleaf pine stands. Sequential annual applications of imazapyr will also lead to pine injury because the effect of this residual herbicide is cumulative, so it is best to use glyphosate alone in alternate years. Common recommendations for spot treatment of cogongrass patches in pine stands include the use of 3 to $4 \%$ glyphosate product (containing $4 \mathrm{lb}$ ai/gallon) plus a 0.5 to $1.0 \%$ solution of Arsenal AC or 1.0 to $2.0 \%$ solution of Chopper (Chopper is less concentrated). To ensure selectivity to pines, observe the limits to the rates of ae imazapyr per acre.

\section{References Cited}

Aulakh, J.S., S.F. Enloe, N.J. Lowenstein, A.J. Price, G. Wehtje, and J.H. Miller. 2014. "Pushing toward cogongrass (Imperata cylindrica) patch eradication: the influence of herbicide treatment and application timing on cogongrass rhizome elimination." Invas. Plant. Sci. Manage. 7:398-407.

Ayeni, A.O. 1985. "Observations on the vegetative growth of speargrass (Imperata cylindrica (L.) Beauv.)” Agr. Ecosyst. Environ. 13:301-307.

Brook, R.M. 1989. "Review of literature on Imperata cylindrica (L.) Raeuschel with particular reference to South East Asia." Trop. Pest Manage. 35:12-25.

Bryson, C.T., and R. Carter. 1993. "Cogon grass, Imperata cylindrica, in the United States.” Weed. Tech. 7:1005-9.

Burnell, K.D., J.D. Byrd, Jr., J.D. Ervin, and P.D. Meints. 2003. "Evaluation of plant growth regulators for cogongrass (Imperata cylindrica (L.) Beauv.) seed development and control." Proc. South. Weed Sci. Soc. 56:342.

Chikoye, D., V.M. Manyong, R.J. Carsky, F. Ekeleme, G. Gbehounou, and A. Ahanchede. 2002. "Response of speargrass (Imperata cylindrica) to covercrops integrated with hand weeding and chemical control in maize and cassava." Crop Prot. 21:145-156. 
Coile, N.C., and D.G. Shilling. 1993. "Cogongrass, Imperata cylindrical (L.) Beauv.: a good grass gone bad." Florida Depart. Of Agric. And Cons. Serv. Bot. Cir. No. 28.

Dickens, R. 1974. "Cogongrass in Alabama after sixty years." Weed Sci. 22:177-9.

Dozier, H., J.F. Gaffney, S.K. McDonald, E.R.R.L. Johnson, and D.G. Shilling. 1998. "Cogongrass in the United States: history, ecology, impacts, and management." Weed Technol. 12:737-743.

Enloe, S.F., N.J. Lowenstein, D.W. Held, L. Eckhardt, and D.K. Lauer. 2013. "Impacts of prescribed fire, glyphosate and seeding on cogongrass, species richness and species diversity in longleaf pine." Invasive. Plant. Sci. Manage. 6:536-544.

Eussen, J.H.H., and S. Wirjahardja. 1973. Studies of an alang-alang, Imperata cylindrica (L.) Beauv. vegetation. Biotropica Bull. No. 6.

Gaffney, J.F. 1996. "Ecophysiological and technical factors influencing the management of cogongrass (Imperata cylindrica)." Ph.D. dissertation, University of Florida, Gainesville, FL.

Garrity, D.P., Kummer, D.M., and E.S. Guiang. 1993. "Country profile: the Philippines." In: Sustainable Agriculture and the Environment in the Humid Tropics. National Academy of Science, Washington, D.C.

Hall, D.W. 1983. "Weed watch ... cogon grass." Florida Weed Sci. Soc. Newsletter 5:1-3.

Holm, L.G., D.L. Pucknett, J.B. Pancho, and J.P. Herberger. 1977. The World's Worst Weeds. Distribution and Biology. Univ. Press of Hawaii, Honolulu, HI. 609 p.

Holzmueller, E.J., and S. Jose. 2012. "Response of the invasive grass Imperata cylindrica to disturbance in the southeastern forests, USA." Forests 3:853-863.

Hubbard, C.E. 1944. "Imperata cylindrica. Taxonomy, Distribution, Economic Significance and Control.” Imp. Agric. Bur. Joint Publ. No. 7, Imperial Bureau Pastures and Forage Crops, Aberystwyth, Wales, Great Britton. 53 p.

Ivens, G.W. 1980. "Imperata cylindrica (L.) Beauv. in West African agriculture." In: Proceedings of BIOTROP workshop on alang-alang in Bogor, 27-29 July 1976. Pp 149-156. Biotropica Special Pub. No. 5, Bogor, Indonesia.
Johnson, E.R.R.L. 1999. "Management of the non-native weed cogongrass (Imperata cylindrica (L.) Beauv.) utilizing an integrated management program." MS Thesis, Univ. of Florida. 87p.

Lippincott, C.L. 2000. "Effects of Imperata cylindrica (L.) Beav. (Cogongrass) invasion on fire regime in Florida sandhill (USA)." Natural Areas Journal. 20(2):140-149.

Ludovic, J., A. Capo-chichi, W.H. Faircloth, A.G. Williamson, M.G. Patterson, J.H. Miller, and Edzard van Santen. 2008. "Invasion dynamics and genotypic diversity of cogongrass (Imperata cylindrica) at the point of introduction in the southeastern United States." Invasive Plant Sci. Manage. 1:133-141.

MacDonald, G.E. 2004. “Cogongrass (Imperata cylindrica) - Biology, ecology and management." Critical Reviews in Plant Science. 23:367-380.

MacDonald, G.E. 2007. "Cogongrass (Imperata cylindrica): Biology, Distribution and Impacts in the Southeastern U.S. In: A Cogongrass Management Guide." Loewenstein N.J. and J.H. Miller eds. Alabama Cooperative Extension System, Auburn School of Forestry and Wildlife Sciences, US Dept. Agric. Forest Service. Nov. 7-8, 2007. Mobile Alabama.

Macdicken, D.A., K.L. Hairiah, A. Otsamo, D. Dugama, and N.M. Majid. 1997. "Shade based control of Imperata cylindrica: tree fallows and cover crops." Agroforest. Syst. 36:131-149.

McDonald, S.K., D.G. Shilling, T.A. Bewick, D. Gordon, D. Hall, and R. Smith. 1996. "Factors influencing cogongrass Imperata cylindrica (L.) Beauv., dispersion, establishment and persistence." Weed Sci. Soc. Am. Absts. 36:46.

Minogue, P.J., J.H. Miller, and D.K. Lauer. 2012. "Use of glyphosate and imazapyr for cogongrass Imperata cylindrica management of southern pine forests." South. J. Appl. For. 36:19-25.

Overholt, W.A., Hidayat, P., Le Ru, B., Takasu, K., Goolsby, J.A., Racelis, A., Burrell, A.M., Amalin, D., Agum, W., Njaku, M., Pallangyo, B., Klein, P.E., and Cuda, J.P. 2016. "Potential biological control agents for management of cogongrass (Cyperales: Poaceae) in the southeastern USA." Florida Entomologist. 99(4):734-738. 
Patterson, D.T., E.E. Terrell, and R. Dickens. 1979.

"Cogongrass in Mississippi." Mississippi Agricultural Forest Experiment Station Research Report 46:1-3.

Ramsey, C.L., S. Jose, D.L. Miller, J. Cox, K.M. Portier, D.K. Shilling, and S. Merritt. 2003. "Cogongrass (Imperata cylindrica (L.) Beauv.) response to herbicides and discking on a cutover site in a mid-rotation pine plantation in southern USA." Forest Ecol. Manage. 179:195-2009.

Ramsey C.L., S. Jose, and D. Zamora. 2012. "Cogongrass (Imperata cylindrica (L.)) control with imazapyr and glyphosate combined with and without four adjuvants." South. J. Appl. For. 36:204-210.

Sajise, P.E. 1976. Evaluation of cogon (Imperata cylindrica (L.)) as a serial stage in Philippine vegetational succession. 1. The cogonal serial stage and plant succession. 2. Autecological studies of cogon. Dissertation Abstracts International B (1973) 3040-3041. From: Weed Abstracts 1976, No. 1339.

Seavoy, R.E. 1975. "The origin of tropical grasslands in Kalimantan, Indonesia.” J. Trop. Geo. 40:48-52.

Shilling, D.G., T.A. Bewick, J.F. Gaffney, S.K. McDonald, C.A. Chase, and E.R.R.L. Johnson. 1997. "Ecology, physiology, and management of cogongrass (Imperata cylindrica)." Final Report, Florida Institute of Phosphate Research. 128p.

Tabor, P. 1952. "Comments on cogon and torpedo grasses: a challenge to weed workers." Weeds 1:374-5.

Tabor, P. 1949. "Cogon grass, Imperata cylindrica (L.)

Beauv., in the southeastern United States." Agron. J. 41:270.

Tanner, G.W., and M.R. Werner. 1986. Cogon grass ... an approaching problem. Gainesville: University of Florida Institute of Food and Agricultural Sciences. Wildlife and Range Sciences Tech. Report nr WRS-5. 4p.

Townson, J.K., and R. Butler. 1990. "Uptake, translocation and phytotoxicity of imazapyr and glyphosate in Imperata cylindrica (L.) Raeuschel: effect of herbicide concentration, position of deposit and two methods of direct contact application." Weed Res. 30:235-343.

USDA NISIC. 2017. US Dept. Agric., Nat. Invasive Sp. Info. Cntr. Cogongrass. http://invasivespeciesinfo.gov/plants/ cogongrass.shtml. Accessed July 6, 2017.
USDA Plants. 2017. Nat. Res. Cons. Serv. Plants DatabaseInvasive and Noxious Weeds. https://plants.usda.gov/core/ profile?symbol=IMCY. Accessed July 6, 2017.

Van Loan, A.N., J.R. Meeker, and M.C. Minno. 2002. "Cogongrass." In: Biological control of invasive plants in the eastern United States. Van Driesche, R. ed., USDA Forest Service Pub FHTET-2002-04. 413p.

Willard, T.R., J.F. Gaffney, and D.G. Shilling. 1997. "Influence of herbicide combinations and application technology on cogongrass (Imperata cylindrica) control." Weed Technol. 11-76-80.

Willard, T.R., D.G. Shilling, J.F. Gafney, and W.L. Currey. 1996. "Mechanical and chemical control of cogongrass (Imperata cylindrica)." Weed Technol. 10:722-726.

Willard, T.R., and D.G. Shilling. 1990. "The influence of growth stage and mowing on competition between Paspalumnotatum and Imperata cylindrica." Trop. Grassl. 24:81-86.

Willard, T.R., D.W. Hall, D.G. Shilling, J.A. Lewis, and W.L. Currey. 1990. "Cogongrass (Imperata cylindrica) distribution on Florida highway rights-of-way." Weed Technol. 4:658-660. 